\title{
USING MATERIAL FLOW COST ACCOUNTING (MFCA) TO IDENTIFY BENEFITS OF ECO-EFFICIENCY AND CLEANER PRODUCTION IN A PAPER AND PULP MANUFACTURING ORGANIZATION
}

\author{
Mishelle DOORASAMY \\ University of Kwa-Zulu Natal, Westville, Durban South Africa \\ e-mail: doorasamym@ukzn.ac.za
}

\begin{abstract}
The aim of this study is to use material flow cost accounting (MFCA) to assess the level at which cleaner production (CP) can improve both environmental and economic performance of an organization. Higher energy and raw material prices are causing CP to grow in relevance and importance. The amount of waste to landfill is increasing steadily. Most companies are using inefficient processes and technologies that are obsolete resulting in higher production costs, which, in turn, affect their profitability and competitiveness. This study was a case study based on a paper manufacturing company using an exploratory qualitative and quantitative research methodology. The MFCA approach was used to assess the efficiency of the steam production process using coal-fired boilers. The results indicated that the process was inefficient resulting in significant negative environmental and economic impact. Environmental costs were hugely underestimated by management, as non-product output costs were not included as part of environmental costs calculated by company. Benefits and barriers to $\mathrm{CP}$ was also brought to the forefront at the conclusion of this research.
\end{abstract}

Keywords: cleaner production, eco-efficiency, inefficient processes, environmental costs, and nonproduct output costs.

\section{$1 \quad$ Introduction}

Waste and emissions are a sign of inefficiency in production. Waste is expensive because of wasted material purchase value and not because of disposal fees (Jasch, 2009). Although most companies are ISO14001 certified because of strict environmental regulations and market pressures, they are still not prepared to change production processes by moving toward cleaner production (CP) technologies. Many have adopted end-of-pipe technology as part of their sustainable practices. However, end-of-pipe technologies only address the problems after the process; they do not address the cause of the problem. This leads to eventual accumulation of waste in landfill sites, which only shifts the focus of the real problem. In order for a company to remain sustainable and to achieve eco-efficiency in their production processes, there is an urgent need to adopt CP techniques and technologies as part of the strategy toward sustainable development. As part of the requirement of ISO14001, it is critical that companies look at ways to achieve sustainable competitive advantage by improving their production process by implementing the use of clean technologies that reduce their raw material input, thereby resulting in lower amounts of waste or at times no waste at all. This will ultimately result in improved environmental performance and increased economic performance (Andrew and Pearce, 2011).

Eco-efficiency results in the company saving on their input material as well as having reduced costs for disposing of waste to landfill. Hence, there is likely to be financial and environmental benefits related to clean production technologies.

The question then raised is that if there are both environmental and economic benefits to cleaner technologies, why are companies reluctant to adopt such technologies as part of their business processes/operations?

Managers are more focused on cost-reduction options using existing technology. Cleaner technologies are more efficient, as they prevent emissions at source. If a solution that does not reduce environmental impact by $100 \%$ is adopted, then it is most likely to be an end-of-pipe treatment, which does not solve the problem at its source but shifts it to another environmental media, for example, dust filters that 
reduce emissions to the air by capturing components that are washed out by rainwater and when the filters are dry, they are disposed of on landfill. These approaches are costly and inefficient (Jasch, 2009). However, relatively newer technologies are unlikely to be replaced by cleaner technologies even if they can result in improved environmental and economic performance. Therefore, when benchmarking environmental costs, life cycle of existing technology must be considered. In the short term, good housekeeping measures or minor improvements are preferred as part of CP strategy. In the medium term, it makes sense that a company may change technology and get closer to state of the art of the industry. It is only in the long term that companies will consider changing state of the art to get closer to the ideal world of zero emissions where all inputs become part of the product. Theoretical standards are used to reflect this ideal world with no waste (Schaltegger, et al., 2012).

This study will add to the body of knowledge on $\mathrm{CP}$ and sustainable development. At the conclusion of this study, managers will be able to evaluate and analyze how they can improve both their environmental and economic performance in the future and attain their sustainability targets, hence the "triple bottom line." Improved competitive advantage will result in higher profitability, which in turn will benefit employees, managers, and other stakeholders in the company.

\section{Problem statement}

Managers of paper mills perceive investments in pollution abatement technologies as "unproductive" because they have "no marketable and quantifiable effect in terms of productivity" (Bras, Realff, and Carmichael, 2004), resulting in the omission of the use of CP opportunities (Baas, 2007, p.121). Large savings potential and opportunities for CP to address environmental issues successfully are not easily identified by companies because there is no monitoring and data collection in place.

The benefits of using environmental management accounting (EMA) in practice as an environmental and sustainability tool to collect, evaluate, and interpret the information needed to estimate the potential for CP saving with particular emphasis on nonproduct output (NPO) costs and to make decisions to choose the right $\mathrm{CP}$ options have been established in several business cases. However, the level of implementation of EMA in practice is low because of the significant gap in academic knowledge concerning EMA and its role in identifying inefficiencies in a production process and benchmarking environmental costs to yield superior environmental and economic performance (Ferreira, Moulang, and Hendro, 2010; Christ and Burritt, 2013; Schaltegger, et al., 2010; Van, 2012).

Although CP has proven to be a good tool, it has not yet been well implemented internally. South Africa's commitment to CP led to the formation of the United Nations Industrial Development Organization (UNIDO) National Cleaner Production Center (NCPC). The National Cleaner Production Centre of South Africa (NCPC-SA) strategy, which focuses on assisting industry to implement cleaner production which requires investment in cleaner technologies, was confirmed at the Cleaner Production conference that took place in Gauteng in June 2013 (Delano, 2013, pp.4). Resource efficiency and cleaner production (RECP) has been integrated into NCPC-SA's services. RECP includes energy efficiency, life cycle assessments, and environmental accounting (South African Cleaner Production Centre, 2013).

\section{Background of company}

The paper and pulp manufacturing process of the company, on which the case study is based, consumes large amounts of natural resources and also generates excessive waste. The rising costs of input resources and increasing environmental cost have had a negative impact on the companies' profitability (Cost Accountant, 2013).

The company has invested large amounts of money on end-of-pipe technologies and the wastewater treatment plant to reduce the negative impact of their production processes on the environment. This has, however, not solved their environmental issues nor has it reduced their resource use in production. The technology used in the steam production process is outdated and obsolete and generates between 20 
and 60 tons of unburned coal ash as hazardous solid waste daily. The company also uses large amounts of water in their production process, resulting in even larger amounts of wastewater effluents, a sign of inefficient production (Environmental manager, 2013).

To ensure their future sustainability and competitiveness, management needs to consider adopting CP techniques and technologies that will address waste issues at its source. According to the CP philosophy, which focuses on resources and resource flows, any reduction in material and energy used will result in fewer emissions (Christ and Burritt, 2013, p.163). $\mathrm{CP}$ is perceived by management as a costly strategy that requires innovation with no financial returns to the company in the short term. They are unaware of how high their environmental costs are, because the company uses conventional accounting methods to allocate costs. EMA can be used as a tool to systematically trace and accurately reallocate environmental costs to the relevant processes and products to enable managers to identify opportunities for implementing $\mathrm{CP}$ and thus improve their environmental and economic performance. Information needed to estimate the potential for $\mathrm{CP}$ savings was facilitated by making use of material flow analysis, a tool of EMA to allocate environmental and material flow costs (Jasch, 2009).

\section{$4 \quad$ Aim and Objectives}

To conduct a cleaner production assessment (CPA) of the companies' current production process using process flow sheet analysis in order to identify any operational inefficiencies and barriers to $\mathrm{CP}$ implementation, assess their current environmental management practices, and benchmark the company's environmental costs by comparing energy and mass balance indicators against technological standards and best-available technology using the MFCA approach.

To identify barriers to CP implementation and highlight the potential benefits of adopting cleaner production technology as compared to end-of-pipe technology based on primary and secondary literature as well as empirical findings.

\section{$5 \quad$ Research Methodology}

A case study research methodology involving quantitative data assessment and exploratory qualitative research analysis technique that will be applied to generate theory from collected data was followed in this study. The CP assessment framework will be used to capture data during the $\mathrm{CP}$ audit process as per the CP model.

The study is based on a case study following a multimethod approach. The researcher implemented both qualitative and quantitative data analysis methods during the study. Case study research leads to more informed basis for theory development. According to Zikmund (2004, pp.173), this methodology provides data for building theory that contributes to existing knowledge by analysis from another perspective.

Although the company employs approximately 300 employees, the study will target only those involved in environmental management issues, production, operations, accounting, and cost control.

\section{Research limitations}

It should be noted that case studies provide little basis for statistical generalization. Analytical generalization can be applied to case studies in which existing theories can be used as a template with which to compare findings of a particular case. The researcher used a theoretical framework to study the case in depth.

The richness and complexity of data collected during case study research means that data is open to different interpretations and potential "researcher bias." Struwig and Stead (2013, p.137) confirm that it is not possible to be $100 \%$ unbiased in a qualitative study and generalizability of findings is often difficult to achieve.

\section{$7 \quad$ Practical implications}

The aims of CP are to use resources more efficiently, reduce the amount of undesired outputs, and improve monetary returns by reducing material and energy consumption. 
In the case study, the boilers used are obsolete, which could lead to inefficient steam production incurring high environmental costs and poor economic performance. CP is not being adopted by the company. The results of the study shows that there are opportunities to improve the environmental and economic performance of the organization by ensuring that technological standards are achieved in the short term and by moving closer to state-of-the art technologies in the medium term.

\section{$8 \quad$ Literature Review}

\subsection{Cleaner production}

a) Definition

CP was defined by the United Nations Environment Program (UNEP) in 1991, and this definition still holds (Cleaner Production, 2013).

Traditionally, most organizations dealt with environmental degradation and pollution problems by ignoring the problem, dispersing the pollution so that its effects are less harmful, or controlling pollution using "end-of-pipe" treatment.

$\mathrm{CP}$ is an approach to environmental management that focuses on the causes of environmental problems rather than the symptoms with the aim of improving environmental performance of products, processes, and services. Traditional pollution control approach focused on "react and treat" approach which is after-the-event; however, CP is proactive technique that is based on the "anticipate and prevent" philosophy.

It has been estimated that through the use of technically sound and economically profitable procedures, $70 \%$ of all waste and emissions from industrial processes can be prevented at source (Bosworth, et al., 2001).

Application of $\mathrm{CP}$ to production processes means conservation of resources, the elimination of toxic raw materials, and the reduction of wastes and emissions. This is applied throughout the life cycle of the product from the initial design phase through to the consumption and disposal phase. CP can be implemented by improved housekeeping practices, process optimization, raw material substitution, new technology, and new product design. Focus of this research is on CP technology implementation. Bosworth et al. (2001) in his publication of CP in a dairy industry clearly stated that the most significant $\mathrm{CP}$ benefits are only attainable through both lateral thinking and technological change. A change in attitude of management and employees of a company are crucial in gaining the most out of CP. The Academy of Science of South Africa (2011, p.111) identified implementing $\mathrm{CP}$ processes as an opportunity to avoid solid waste and reduce greenhouse gas (GHG) emissions in the eThekwini Municipality. The promotion of CP will need to be driven by a champion, together with support from the Municipality and commitment from the organization in order to significantly reduce wastage and quantities of waste going to landfill.

CP has gone a step further to now establish the monetary value of data for material flows to identify potential opportunities for savings, and strategic decisions can now be made to invest in CP technology, which could ultimately reduce environmental impact of residual materials and improve resource efficiency. This system overcomes the weakness of the previous environmental methods that are used to calculate material balance purely on volume basis. This method requires an initial capital outlay and no cash inflow or net present value (NPV) calculations (Schmidt and Nakajima 2013, pp.358-369).

Research in a milk processing company by Dvarioniene, Kruopiene, and Stankeviclene (2012, pp.1037-1045) aimed at identifying the effect on environmental efficiency by the application of CP and eco-design as sustainability tools. It had been realized that in order to ensure that production processes are sustainable, improvement of process efficiency is an important element. Hence, the need for CP became apparent. The milk industry similar to the paper manufacturing industry is very resource intensive and also generates many by-products and wastes during each process. Thus it does have a polluting impact on the environment. The Lithuanian milk processing company used in the case analysis was found to have used technologies that were obsolete, low working productivity, and ineffective use of raw materials, and they did not meet modern market requirements. The case study being done in this research also has the same problem with regard 
to old obsolete technologies being used in their production processes. To survive in a dynamic business environment, innovations play an important role. Technological and organizational innovations are crucial in order to change a company's profile into becoming environmentally, economically, and socially sustainable. The methodology applied by Dvarioniene, Krupiene, and Stankeviclene (2012, pp.1037-1045) was the use of environmental efficiency indicators to evaluate the company's environmental performance, and for comparison with Best Available Technology (BAT) values. It had been concluded that sustainability improvements were possible but only through technological process innovation. Eco-design was used to improve packages and the environmental impact of packages.

Alexopoulos, Kounetas, and Tzelepis (2012, pp.623) investigated the possible link between the environmental performance and the level of technical efficiency achieved by Greek listed firms by using their corporate financial data to gauge their environmental performance. Empirical evidence suggests that higher environmental performance is a direct result of more efficient processes, improved productivity, and reduced regulatory or compliance costs. Hence, in order to improve efficiency of production processes, there is definitely a need to ensure optimal technical efficiency. This in turn leads to new market opportunities and increased competitive advantage for the organization.

CP implementation techniques in developing countries are as follows:

- Good Housekeeping: prevention of leaks and spills by proper maintenance procedures and standardized operations,

- Input Material Change: replacement of hazardous and non-renewable material inputs by less hazardous and renewable material,

- Better Process Control: working procedures and process record keeping to ensure higher efficiency and reduced waste generation by optimal operational processes,

- Equipment Modification: production equipment modified to achieve higher efficiency and lower rates of waste and emission generated,
- Technology change: technology replaced to reduce waste and emission generated during production,

- On-Site Recovery/Reuse: wasted material reused in the same process or another useful application within the company,

- Production of Useful By-Products: previously discarded material being transformed into reusable product,

- Product Modification: product modification in order to reduce environmental impact of its production processes.

\section{b) Cleaner Production Assessment}

A CPA involves the systematic implementation of procedures to identify inefficient resource consumption and poor waste management. This information is then used by companies to develop $\mathrm{CP}$ options (Delana, 2013). The UNEP and UNIDO developed basic steps to conduct CPA:

- Planning and organizing the CPA,

- Pre-assessment (gathering qualitative data about the organization and its activities),

- Assessment (gathering quantitative information about the organization and its activities),

- Evaluation and feasibility assessment of CP opportunities,

- Implementation of $\mathrm{CP}$ opportunities identified and a plan to continue with $\mathrm{CP}$ efforts.

Bosworth, Hummelmose, and Christiansen (2001) were actively involved in producing the guide on "Cleaner Production Assessment in Diary Processing," from which the information on CPA was obtained and mentioned in this report. The aim of this publication was to enable organizations to enjoy the benefits that $\mathrm{CP}$ had to offer.

\section{c) Types of cleaner production options}

Bostworth, et al. (2001) provided a list of the types of CP options available to organizations as stated below:

- housekeeping - proper maintenance and improvements to work practices can produce benefits at low costs to the organization, 
- process optimization - optimizing existing processes can reduce resource consumption at low to medium cost,

- raw material substitution - replacing hazardous materials with more environmentally benign materials can reduce environmental problems. This may require changes in process equipment,

- new technology - minimum waste generation, reduced resource consumption, and improved operating efficiencies are achievable by adopting new technologies; this is a capital-intensive option; however, payback periods are short,

- new product design - changing product design can bring about benefits throughout the life cycle of the product such as reduced waste disposal, reduced energy consumption, and more efficient production processes; this is a long-term strategy and may require new production equipment.

\section{d) Benefits of cleaner production}

"Cleaner Production Assessment in Dairy Processing" by Bosworth, et al. (2001) reported the following as reasons to invest in $\mathrm{CP}$ :

- product and process improvement,

- reduced production cost through savings on raw materials and energy,

- new and improved technologies increase competitiveness of the organization,

- environmental legislation and regulatory compliance,

- treatment, storage, and disposal of hazardous waste liability is reduced,

- health, safety, and morale of employees as well as company image are improved,

- end-of-pipe solution costs are reduced.

$\mathrm{CP}$ is seen as a "win-win" strategy that enables a company to achieve sustainability goals while also improving industrial efficiency, profitability, and competitiveness. Developing countries and those undergoing economic transition can especially benefit from CP that provides an opportunity to "leapfrog" those more established industries.

$\mathrm{CP}$ technologies and equipment have been developed by many industrialized countries to decrease pollution and emissions quantities and to meet regulatory standards. In order to minimize ash and gas emissions, waste water discharge, and other environmental impact, pollution control methods should be substituted by CP techniques (Liu et al., 2013).

e) Empirical studies conducted on Cleaner Production (CP) and Environmental Management Accounting (EMA)

Numerous pilot studies have been undertaken by $\mathrm{CP}$ experts and have demonstrated that $\mathrm{CP}$ is a sign of more efficient production and companies that have adopted CP have reported reduction in cost and environmental impact at the same time (Schaltegger et al., 2010, pp.4-11).

There is a growing demand of raw materials by paper industries as a result of worldwide increase in the production and consumption of paper and paperboard. It is expected that paper consumption will increase to over 490 million tons per year by 2020 (Mousavi et al., 2013, pp.420-424). Strict environmental legislation, market pressures, and the urgent need for sustainability have created a major challenge for the paper and pulp industry (Despeisse, Oales, and Ball, 2013, pp.31-41). This has led to the introduction of sustainable development in business practices (Persson and Berntsson, 2010, pp.935-943).

In order to achieve sustainable competitive advantage, businesses need to adopt $\mathrm{CP}$ processes. According to the UNEP, CP is defined as "the continuous application of an integrated preventative environmental strategy to processes, products, and services to increase overall efficiency and reduce the risk to humans and the environment" (Fore and Mbohwu, 2010, pp.314-333; Pons, et al., 2013, pp.134).

Although a growing number of organizations in both manufacturing and service sectors demonstrated the potential to successfully reduce both their operating costs as well as environmental impact, the implementation of $\mathrm{CP}$ has been slow and lagging. Pilot studies by CP experts remain merely as niche examples and decision makers in companies have failed to adopt this as a corporate strategy because of the shortcoming in the discrimination of information about the economic and environmental potential of CP (Schaltegger, 2010, pp.5-11). 
The United Nations Development Programme, as part of the Department of Sustainable Development, reports EMA as an important management tool for businesses to adopt while responding to environmental challenges and still focusing on the triple bottom line (Ambe, 2007, p.7). UNEP educates and encourages companies on the benefits of using EMA. Following these international developments, South African companies have considered environmental issues in their decision-making processes regarding products and processes. South African companies have identified potential savings of implementing good environmental management by using EMA to accurately trace and identify environmental costs (Ferreira, et al., 2010; Christ and Burritt, 2013, p.165; Ambe, 2007, pp.11-12). A study conducted by Jonall $(2008$, p.2) by reviewing articles in academic journals revealed that the EMA method identified material purchase value of NPO costs to be the largest cost category.

A test project undertaken by Schaltegger, et al. (2010, pp.17-19) to assess the sustainable performance of companies after a combined application of EMA, CPA, and EMS (Environmental Management Systems) generated positive outcomes and contributed to the enhancement of CPA/EMS projects by increasing awareness of the economic implications of the environmental impact of NPO and costs and provided a systematic method of controlling these costs in the short, medium, and long terms. EMA also helped to quantify monetary benefits of adopting alternative CP options (Van, 2012, p.5).

Cleaner technologies shared environmental gains of less pollution and reduced waste generated at the end of the production process and financial gains of lower maintenance costs and more efficient use of raw materials. Positive results were concluded in all departments in the environmental management system whereby the clean technology had been deployed (Promoting Sustainable Use of Industrial Material, 2013; Acemoglu, et al., 2012, p.1).

The "Porter Hypothesis" of the win-win scenario suggests that well-designed environmental regulation can inspire innovation and strategy formulation aimed at "enhanced resource productivity" that could make companies more competitive (Bras; Realff and Carmichael, 2004; Foelkel, 2008, p.4). This change toward CP processes may require investment in CP technologies (Christ and Burritt, 2013, p.163; Schaltegger, et al., 2012, pp.11-15). Actions generated in clean technology should no longer be seen only as costs, as they represent a number of benefits to industries by assisting them in their endeavors in sustainable development and achieving their goals of the "triple bottom line" (Mendes, 2012, p.100).

The Cleaner Production conference, which was held in Gauteng in June 2013, illustrated the impact and profitability of the RECP program and highlighted that materials and resource efficiencies can improve competitiveness, sustainability, and profitability of local manufacturing industry (Delano, 2013, p.3).

\section{f) Role of Environmental Management}

Accounting (EMA) in cleaner production implementation

The United Nations Development Programme, as part of the Department of Sustainable Development, reports EMA as an important management tool for businesses to adopt while responding to environmental challenges and still focusing on the triple bottom line, which is achievement of environmental, social, and economic benefits by the company (Ambe, 2007, p.7). UNEP educates and encourages companies on the benefits of using EMA. Following these international developments, South African companies have considered environmental issues in their decision-making processes regarding products and processes. South African companies have identified potential savings of implementing good environmental management by using EMA to accurately trace and identify environmental costs (Ferreira, et al., 2010; Christ and Burritt, 2013, p.165; Ambe, 2007, pp.11-12).

Fig. 1 illustrates a tool of EMA used to measure the physical and monetary unit flows of material in the manufacturing process to identify accurate cost of waste and emissions for substantial cost reduction. 

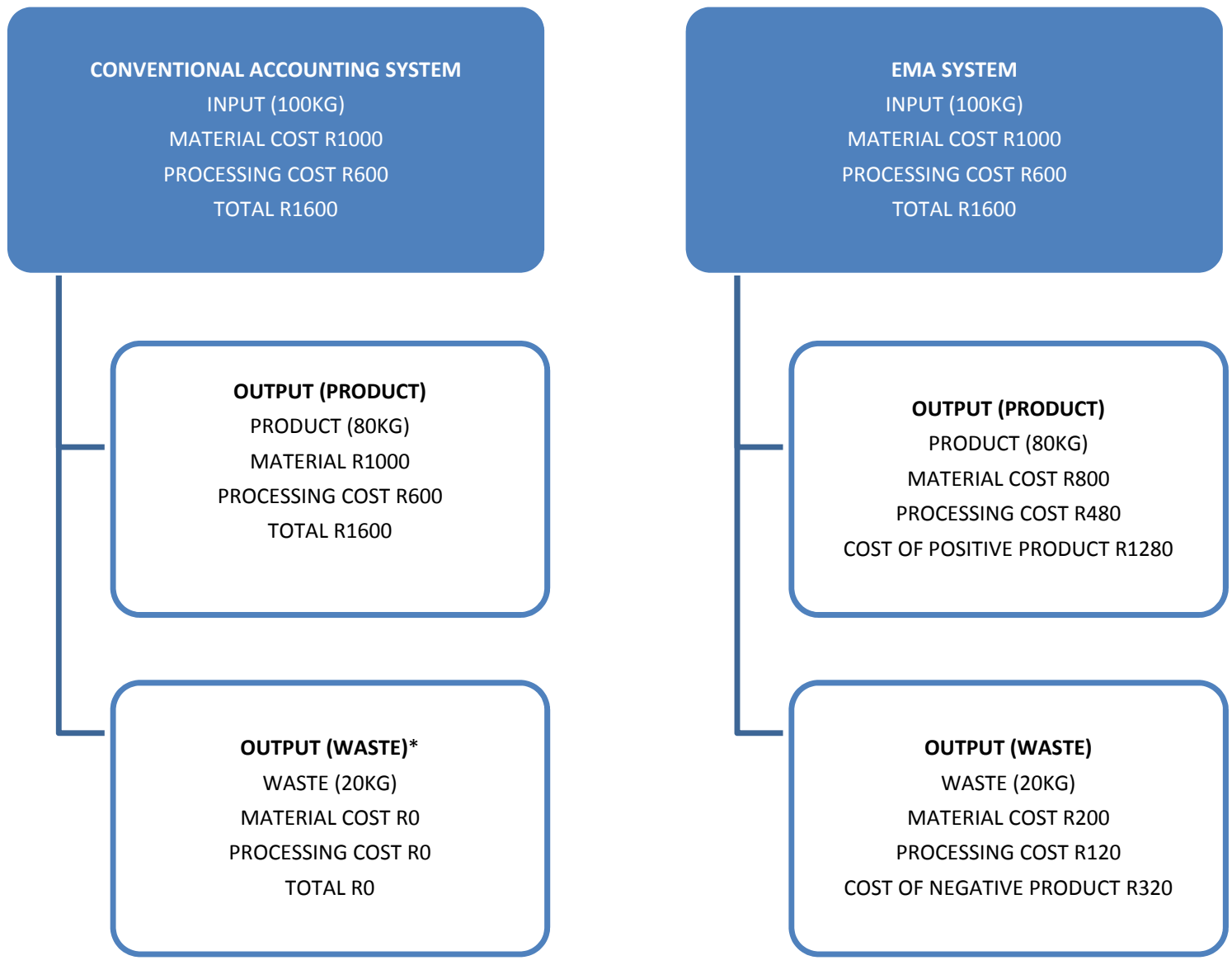

Figure 1. Model of material flow cost accounting

(source: Model first developed in Germany in 1999; thereafter, it was modified by Ministry of Economic, Trade and Industry of Japan, 2007)

\subsection{Contextual factors of paper and pulp manufacturing}

Excessive production capacity, high fixed costs, cutthroat pricing schemes, increasing competition from foreign impacts, yet still producing more paper even though this meant higher marginal cost implications of the law of diminishing returns (Bras, et. al., 2004)

Paper and pulp manufacturing operates in a cyclical industry with global economic conditions causing volatility in paper and pulp prices. Therefore, cost reduction and improving efficiencies are considered a priority. Finding lower-cost raw materials and alternative fuels, minimizing waste, improving manufacturing efficiencies, and implementing energy saving initiatives are some measures implemented by the industry to mitigate risks (Zarkovic, et al., 2011).

The paper and pulp industry has improved their environmental performance dramatically since 1970 . Mill managers view investments in pollution abatement technologies as "unproductive with no marketable and quantifiable effects in terms of productivity". According to Porter, the cost of environmental equipment is made up of capital cost and cost of nonvalue-added activities (associated with regulatory compliance, operation and maintenance of equipment, permitting and reporting). The United States had installed pollution-control technologies to remove specific substances from the air and water releases since the 1970s. However, recently, pollution prevention technologies, a more conservative approach to environmental protection than pollution control, has been introduced. Total composition of effluents discharged and its potential environmental impacts is not completely known to many; therefore, pollution prevention is the only solution to help reduce the probability of unwanted surprises being released into the environment (Zarkovic, et al., 2011). 
However, changing from pollution-control to pollution-prevention technologies takes time, money, and a holistic approach to managing the environmental issues associated with pulp and paper manufacturing. Pollution-prevention technology investments can be costly and often compete for capital funds together with other projects that would also improve the company's profitability. In order to remain competitive, mills will have to respond with new technologies, and if this decision results in the firm incurring high costs, these costs are most likely to be passed on to purchasers. Therefore, paper companies must consider how much capital needs to be invested in order to reduce operating costs.

Minor renovations, replacement of individual pieces of equipment, and the elimination of bottlenecks will have to proceed at a greater rate than major renovations or expansions. It can be concluded that integrating pollution-prevention strategies into pulp and paper manufacturing need to be part of the capital planning process that integrates a long-term vision for environmental progress with improvements in quality, productivity, and lower operating costs (Zarkovic, et al., 2011).

Bras, et al. (2004) suggest that capital expenditures on pollution abatement result in a loss of productive capital. The general view is that "every penny spent complying with green rules means a penny less spent on building more mills." Porters' hypothesis of the "win-win" scenario states that if environmental regulation were properly designed, it can inspire innovation that will allow companies to use their inputs more productively to offset the costs of improving environmental impact. Empirical studied conducted on paper and pulp industry found that paper industry input use and pollution could be reduced from between $2 \%$ and $8 \%$ without adverse effects on productive output. Porter suggested that a strategy aimed at enhanced resource productivity will make companies more competitive. The two impediments that were identified to using environmental issues to gain competitive advantage were ignorance about direct and indirect environmental impact and limitations of conventional accounting systems for tracking environmental costs (Zarkovic, et al., 2011, pp.1139-1145).
Investing in technologies to improve the company's ability to identify and quantify "win-win" capital investment and operational improvement opportunities through improved access to and analysis of production and environmental accounting information can support decisions of a corporate commitment to profitability and sustainability.

\subsection{Non-Product Output}

The most significant share of total environmental costs is usually non-product output costs. An EMA system can provide information needed that could be used for directing decisions toward the adoption of CP measures by implementing new technologies to reduce these costs (Peres, Domil and Pere, 2010).

The purpose of material flow balance as explained by Jasch $(2009$, p.832) is to completely understand how much of what is put into the system becomes a product and how much becomes NPO. He suggests that understanding NPO is the best way to manage environmental issues. The generation of waste or NPO is a sign of inefficient production. Therefore, material flows is important not only for the assessment of environmental cost but also for the production-oriented cost assessment. It had been concluded that material flow cost accounting (MFCA), although in its imperfect form, is a powerful tool to ensure the future sustainability of a business. Schmidt and Nakajima (2013) concluded that a key concept of MFCA is to distinguish between product cost and NPO and to evaluate which streams of material ends up as part of the final product and which streams of material are NPO. Once material losses are quantified, improvement measures and opportunities to reduce costs by avoiding material losses are identified. Monetary savings are higher if the company assessed only direct costs of waste disposal for the residual materials. Knowing the complete costs allows for scope for technical measures in order to reduce material loss. This is made possible by MFCA analysis.

One of the major cost drivers reported during company workshop studies was the material purchase value of NPO (Jonall, 2008, p.32). NPOs are a major cost factor for companies considering that polluting companies actually pays three times for NPO. 
First, the cost of purchasing the raw material which end up as wasted material. Second, the company incurs costs for operational use of raw material, for example, labor and investment cost. Finally, the company then pays for the disposal of this wasted material (Jonall, 2008, p.42). This is the actual cost of the wasted material that most companies fail to realize. Making them aware of this can create the need to improve material efficiency by investing in newer, $\mathrm{CP}$ technologies.

It is suggested that these costs have to be calculated annually for internal reporting purposes and to assist managers in making important investment decisions.

\subsection{End-Of-Pipe technology versus Cleaner Technology}

"Timing" is the key difference between pollution control and cleaner production. Pollution control is after the event, whereas CP is a proactive approach focused on prevention. Bosworth et al. (2001) mentioned that there should not be a misconception that "end-of-pipe" technologies will never be required. Using CP to handle the waste problems would merely reduce the dependence of "end-of-pipe" technologies or, in some cases, eliminate its use completely.

Jasch (2009, p.833) states that focusing on end-ofpipe solutions rather than cleaner technologies that prevents emissions at its source will not provide an accurate assessment of opportunities for potential savings of resource use. Bosworth et al. (2001) concur that $\mathrm{CP}$ options are more cost effective when compared to pollution control options and savings are generated through reduced cost of raw materials, energy, and waste treatment. Market opportunities for "greener" products are identified as an environmental benefit of CP.

Jonall $(2008$, p.42) stated that although prevention and environmental management costs have been high in the cases studied but considered low when compared to waste and emission treatment, which is by far the largest cost category constituting of about three-fourth of estimated EMA costs. This ultimately means that the company has spent a lot on end-ofpipe treatment.

It should be, however, noted that improvements with existing technology is possible but with minimum amounts of savings. Production process efficiency is highly dependent on what efficiency is possible with the best affordable technology. Neither the best available technology nor the best affordable technology would be able to achieve $100 \%$ efficiency in output in relation to the input. Processes without losses of energy and material are nearly impossible to achieve. However, practical research in business organizations reveals examples where proactive prevention initiatives have brought about both environmental and financial benefits for firms as compared to reactive end-of-pipe approaches, which are expensive and camouflaged through hidden costs.

From the mid 1970s, pollution prevention was realized to be the desired environmental management strategy (Environmental strategies, 2013). The reduction and possible elimination of waste makes good environmental and business sense. Clean technologies reduce emissions below required levels, hence, lower compliance and liability costs. End-ofpipe technologies results in higher investment costs with no increase in the efficiency of production, as pollution-control technologies are non-productive assets. Environmental technologies lead to sustainable cost advantage, as they are difficult to imitate by competitors as compared to end-of-pipe technologies that are off-the-shelf solutions and can be easily acquired in any market. Environmental technologies (clean technologies) require a firm's production process to be changed, whereas end-of-pipe technologies are added to existing production processes.

\section{Data analysis and Findings}

\subsection{Review of company data on steam production process}

This section deals with primary data collection and analysis of the steam generation process to identify the possible saving opportunities and improved environmental performance by adopting $\mathrm{CP}$ techniques. The first step in the process involves a CPA of the steam generation process.

Coal input and steam production output of boilers:

- Data from the input/output schedule of the steam production process for the period under review (October 2012 to September 2013) are used to test the efficiency of the boiler technology against technological standards. 
- According to technological standards of the company's current boiler technology, the standards input/output ratio of coal and steam generated is 1:7. However, the input/output schedule indicates the actual amount of coal used for the 12-month period. This ratio is compared to technological standards of 1:7 to identify technological inefficiencies of the steam generation process.

\subsection{Cleaner Production Assessment (CPA)}

The qualitative review was conducted during the CPA stage. It involved an overview of the company's production and environmental aspects. The CPA framework was used to capture data during the $\mathrm{CP}$ audit process as per the $\mathrm{CP}$ model. Analysis of the process flow chart shows inputs, outputs, and environmental problem areas of the steam generation process. Quantitative data analysis involved calculation of NPO using MFCA, a tool of EMA.
This was used to identify potential savings options for the company should they adopt CP processes. Schaltegger et al. (2010) highlighted the following warning signs of inefficiencies that become evident during the CPA: higher raw materials cost compared to those prescribed by technological standards, higher energy costs, maintenance needs, and higher level of undesired output.

The first step of CPA involves the process flow chart analysis of steam generation process, to identify waste generated resulting in negative environmental impact.

\subsection{Ash Disposal}

Fig. 2 is a design process flow chart of the boiler. It depicts the steam production process and ash disposal from the boiler plant.

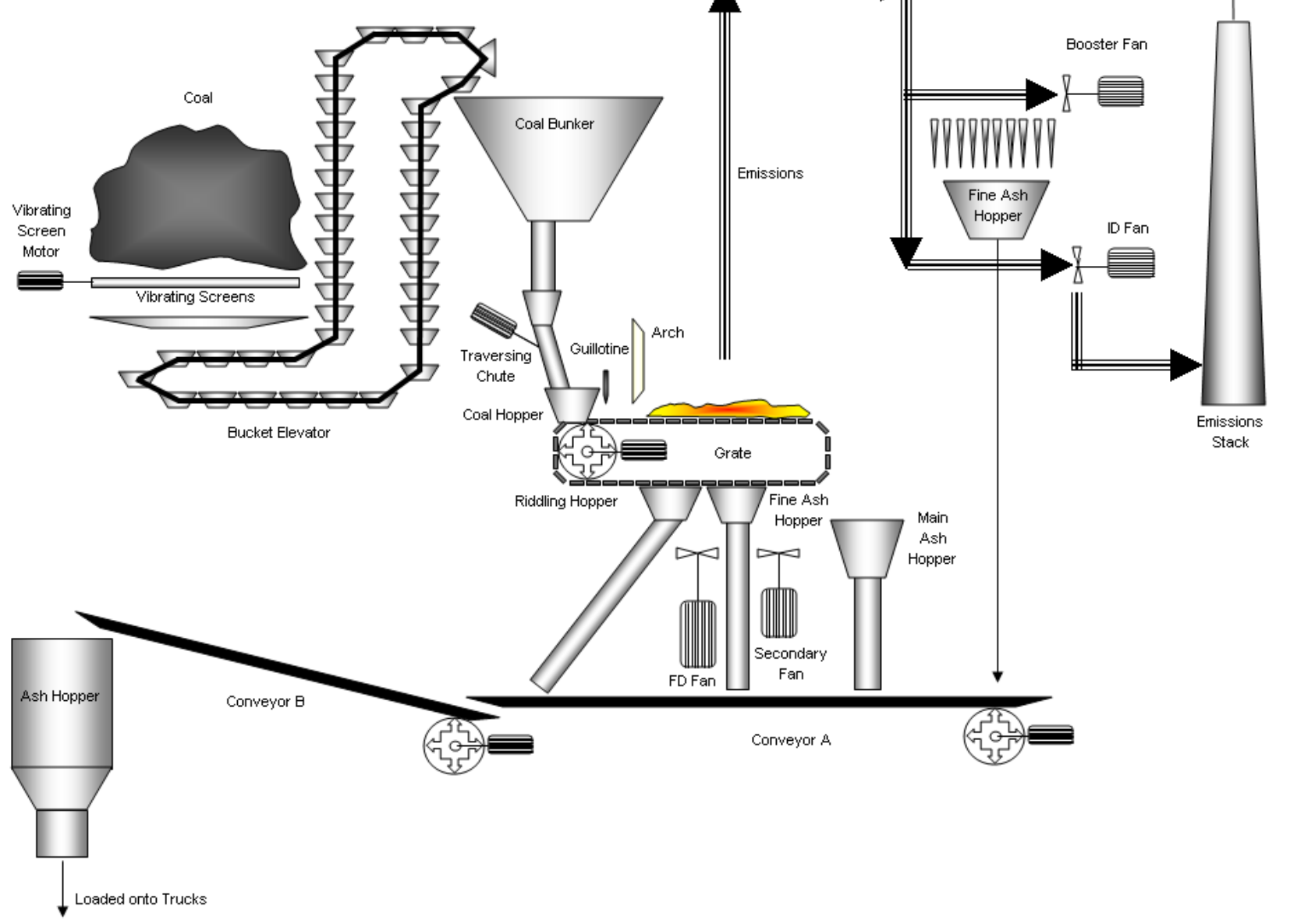

Figure 2. Coal-fired steam boiler technological process flow chart 
Burnt coal of the grate, dust from the dust cyclones, grit particles from the Riddling Hopper (mainly grit), and fine ash from soot blowing are waste products that are disposed via the ash disposal system. Before being deposited onto the ash conveyor, the ash from the main ash conveyor is first cooled. The ash and burning coal is drops into a containment facility. Here water is added to cool and quench the burning coal. A paddle ash extractor is used to transfer the resulting waste onto the ash conveyor. This consists of a paddle disc that is powered by a motor.

- Boiler 1: Ash conveyor is powered by motor C081,

- Boiler 2: Ash conveyor is powered by motor C082,

- Boiler 3: Ash conveyor is powered by motor C083, and

- Boiler 4: Ash conveyor is powered by motor C084.

The ash of each boiler ash conveyor is deposited onto the main ash conveyor A and then B. Main ash conveyor A is powered by $\mathrm{C} 086$, while main ash conveyor $\mathrm{B}$ is powered by $\mathrm{C} 86 \mathrm{~A}$.

Ash is then deposited into the ash hopper where it is then loaded onto trucks and disposed onto landfill sites.

a) Coal input and steam production output of boilers

Data from the input/output schedule of the steam production process for the period under review (October 2012 to September 2013) is used to test the efficiency of the boiler technology against technological standards and BAT standards.

Table 1 indicates the one-sample KolmogorovSmirnov test, which is performed to determine the nature of the distributions.

As all of the p-values are greater than 0.05 , it implies that the distributions are all normal. Hence, parametric testing (t-tests) were performed.

Fig. 3 illustrates comparative results relating to output and input ratios.

Table 1. One-sample Kolmogorov-Smirnov test

\begin{tabular}{|l|l|c|c|c|c|}
\hline \multicolumn{2}{|l|}{} & Boiler 1 & Boiler 2 & Boiler 3 & Boiler 4 \\
\hline \multirow{2}{*}{$\mathrm{N}$} & 12 & 12 & 12 & 12 \\
\hline \multirow{2}{*}{ Normal parameters a,b } & Mean & 6.7062 & 6.5326 & 6.4092 & 6.5773 \\
\cline { 2 - 6 } & $\begin{array}{l}\text { Standard devi- } \\
\text { ation }\end{array}$ & 0.25947 & 2.61052 & 0.71007 & 0.36191 \\
\hline \multirow{2}{*}{\begin{tabular}{l} 
Most extreme differences \\
\cline { 2 - 6 }
\end{tabular}} & Absolute & 0.198 & 0.341 & 0.144 & 0.133 \\
\cline { 2 - 6 } & Positive & 0.155 & 0.336 & 0.110 & 0.099 \\
\cline { 2 - 6 } & Negative & -0.198 & -0.341 & -0.144 & -0.133 \\
\hline Kolmogorov-Smirnov Z & 0.688 & 1.180 & 0.500 & 0.461 \\
\hline $\begin{array}{l}\text { Asymptotic significance (two-tailed) } \\
\text { a Test distribution is Normal } \\
\text { b Calculated from data }\end{array}$ & 0.732 & 0.123 & 0.964 & 0.984 \\
\hline
\end{tabular}




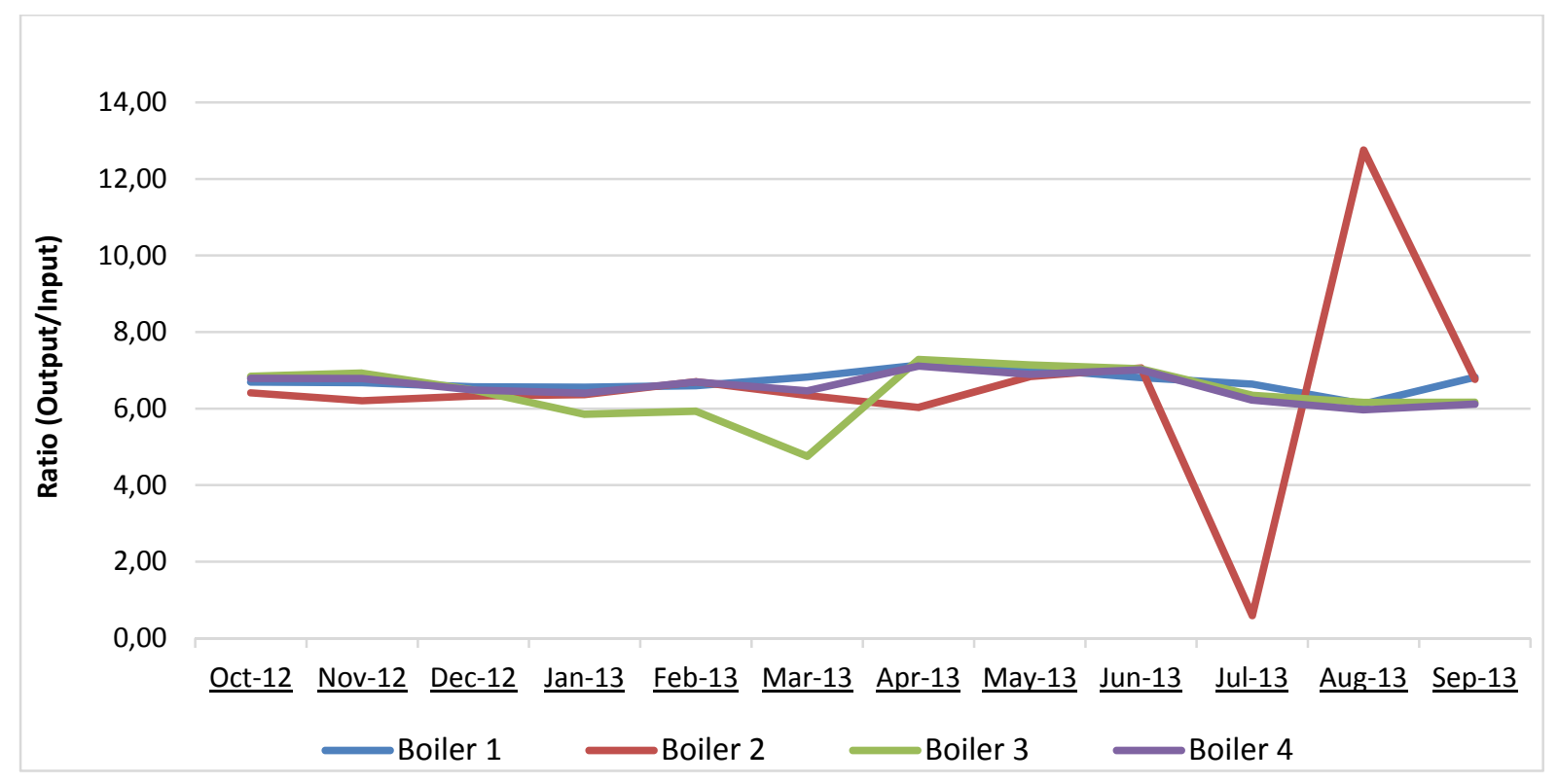

Figure 3. Output-to-input ratio (source: Doorasamy, 2014)

The mean ratio values per boiler (Table 1) were then determined and compared to the standards (converted to a ratio as well).

Only boiler 2 is not significantly different. The other three boilers are different. The three means are significantly less than the standard of 7 . This implies that the company's current technology is not operating according to design specification. This is, therefore, a sign of an inefficient production process.

The NPO costs at this level can be reduced by better housekeeping, for example, better monitoring of raw material consumption, avoiding scraps and wastes, and reducing energy and water consumption. This information needs to be generated on a monthly basis for companies to react faster.

b) Breakdown and calculation of losses incurred in steam generation process for period under review, October 2012 to September 2013.

Table 2 shows the variance in coal usage by comparing the actual usage to allowed usage.

Table 2. Year-to-date variance in tons and Rands

(source: M. Doorasamy, 2014)

\begin{tabular}{|c|c|c|c|c|c|c|}
\hline & $\begin{array}{c}\text { Allowed } \\
\text { usage in tons }\end{array}$ & $\begin{array}{c}\text { Actual usage } \\
\text { in tons }\end{array}$ & $\begin{array}{c}\text { Variance } \\
\text { in tons }\end{array}$ & $\begin{array}{c}\text { Allowed usage } \\
\text { in Rands }\end{array}$ & $\begin{array}{c}\text { Actual usage } \\
\text { in Rands }\end{array}$ & $\begin{array}{c}\text { Variance } \\
\text { in Rands }\end{array}$ \\
\hline Coal & 74,065 & 76,022 & $-1,956,696$ & R69,106,650 & $\mathrm{R} 70,923,659$ & $-\mathrm{R} 1,817,009.25$ \\
\hline
\end{tabular}

Table 2 shows that the actual usage of coal was higher than the allowed usage of coal for the amount of steam generated, resulting in a negative variance of R1, 817,009.25. Note: Gross production of steam for the period under review was $517,938.000$ tons per year.

It should be noted that a negative variance in coal usage for the year ended September 2013, resulting in a loss of R1, 817,009.25 according to accounting records, could be attributed to the inefficiency of their current technology used in the steam production process. The excess usage of coal impacts negatively on the environment and decreases the economic performance of the company in terms of more costs for raw material used in the steam production process. 
c) Causes of waste generated during steam production process

During the steam generation process, large amounts of unburned coal are found in the bottom of the boiler ash. Hence, the steam production process is inefficient, resulting in excessive raw material wastage. Input/output ratio according to technological design is not being achieved. Therefore, the amount of coal used to generate steam is in excess to what is prescribed in the technological flow chart manual. The information above indicates that the three of the four boilers are functioning well below test standards of 1:7 and state-of-the-art technological standards of $1: 8$. The only boiler that is functioning close to the design specification is boiler 2. In order to identify operational savings, managers need to look at ways to reduce the NPO costs caused by suboptimal functioning of boilers.

It should be noted that the total cost of material losses was limited to raw material flow only. No energy costs or water costs will be included in the calculation. Material purchase value of NPO is the most significant of all costs incurred in process steam.

Cost categories such as material cost, system cost, and energy cost are included in the total cost of the steam production process. Unburned coal/carbon content of boiler ash (solid waste) has been estimated to identify NPO costs of raw materials that do not form part of the final product (steam). Material loss/waste is quantified and calculated using the purchase price of coal. Monetary value of NPO is calculated using the following equation:

Monetary value of loss $=($ Quantity loss in tons $) \times$ (Input price of coal)

Case study findings reported by The Cleaner Production Case Studies Directory EnviroNET Australia (2003) presented results of a CPA that was done on coal-fired boilers used by the AMH group, which operated five coal-fired boilers, situated at different sites. The CPA revealed differences in coal burning performances of the boilers and opportunities to improve boiler performance were identified. It had been found that between $2 \%$ and $29 \%$ of coal used were not combusted. The unburned coal that remained in the boiler ash was disposed to landfill. Two of the five boilers revealed poor performance.
The investigation showed significantly high production costs because of wasted energy and higher steam costs. A thorough investigation was done on the process involving the two underperforming boilers to identify possible causes of the inefficiencies identified during the CPA. It had been found that the boiler operating staff had difficulty in operating the boilers to meet steam demand. The company conducted an in-house training program to develop operating and management skills of staff involved in operating the boilers. The program was successful, resulting in immediate reduction in percentage of unburned coal from $25 \%$ to $2 \%$ and improved boiler efficiency from $70 \%$ to $98 \%$. Coal usage decreased by $27 \%$, resulting in a savings of approximately $\$ 65,000$. An added benefit was reduced ash disposal to landfill by 275 tons per year. It is important to note that the case study cited above had a similar problem as the study currently being researched.

\section{d) Current accounting practices for managing environmental cost of the company}

The standard accounting information system is used for both financial and management accounting. Only monetary information is provided for environmental costs. For the steam generation process, no environmental costs were included. Production costs for the process included raw material (coal), electricity, water, and fixed cost. All coal purchased was included as part of production costs. Raw material lost during production was not calculated and measured in monetary and physical terms. The NPO is an environmental cost to the company, as this loss represents waste that is a sign of inefficiency in production.

Depreciation of environmental equipment should be recognized as part of environmental costs and not fixed overhead costs. Labor cost of handling and disposal of waste including the salary of the environmental manager should be allocated to environmental cost. However, this is not being done by the company. Environmental costs are allocated to overhead accounts and key managers are not held liable for these costs. This tends to discourage managers from actively managing environmental costs. There is limited environmental accountability. 
Based on the above information regarding accounting practices for managing environmental cost, it can be concluded that because of the inadequacies of the company's current accounting systems, environmental costs reported by the company are significantly underestimated. The environmental costs included in financial statements are not a true and accurate reflection of the actual environmental costs.

There seems to be poor communication between the management accountant and the environmental manager. Management accountants tend to be constrained to thinking within the existing chart of accounts and pay less attention to environmental costs (Chang, 2007). Owing to this break in communication, opportunities for reducing environmental costs remain unidentified. In order to build a link between physical and monetary information systems and improve environmental and economic performance, it is essential that there be regular interaction and information sharing between the environmental and accounting departments.

\subsection{Data analysis of Questionnaire}

All of the sections have reliability scores (Table 3 ) that exceed the minimum required value of 0.700 , except for investment in environmental performance, which is slightly below the standard value. This was due to a negatively worded statement in this section. The first question only had one statement that does not allow for a reliability calculation.

Table 3. Reliability scores on questionnaire

\begin{tabular}{|c|c|c|}
\hline & $\begin{array}{l}\text { Number } \\
\text { of Items }\end{array}$ & Cronbach's Alpha \\
\hline Company's environmental performance & - & - \\
\hline Environmental issues addressed & 8 of 8 & 0.948 \\
\hline Investment in environmental performance & 3 of 4 & 0.621 \\
\hline $\begin{array}{l}\text { Benefits of a system designed to measure and manage environmental } \\
\text { performance }\end{array}$ & 7 of 7 & 0.927 \\
\hline $\begin{array}{l}\text { Challenges of applying a systems to measure and manage environmental } \\
\text { performance }\end{array}$ & 6 of 6 & 0.797 \\
\hline $\begin{array}{lll}+2 & \text { overall }\end{array}$ & 24 of 24 & 0.823 \\
\hline
\end{tabular}

The data analyzed above indicates that all of the environmental issues stated above are recognized and being addressed by the company to improve environmental performance.

Fig. 4 illustrates benefits of cleaner production in KwaZulu-Natal (Doorasamy, 2014).

The analysis detailed above indicates that $85.75 \%$ of the respondents agree that the company has invested sufficiently in improving its environmental performance. It can be perceived that managers may consider further investments to improve environmental performance in the future. However, not much can be done to improve environmental performance with the above information as the company currently uses a traditional cost accounting system. This system is adequate to provide additional information needed to make future investment decision to reduce environmental costs. Shaltegger et al. (2010, p.144) concur that a company will only adopt an EMA system if they are made aware of what can be gained by using it. They argue that more accurate awareness of process and product cost is an insufficient reason and offer uncertain benefits. Accountants need to know how much they can save with particular emphasis on NPO costs.

The results of chi-square test are shown in Table 4. 


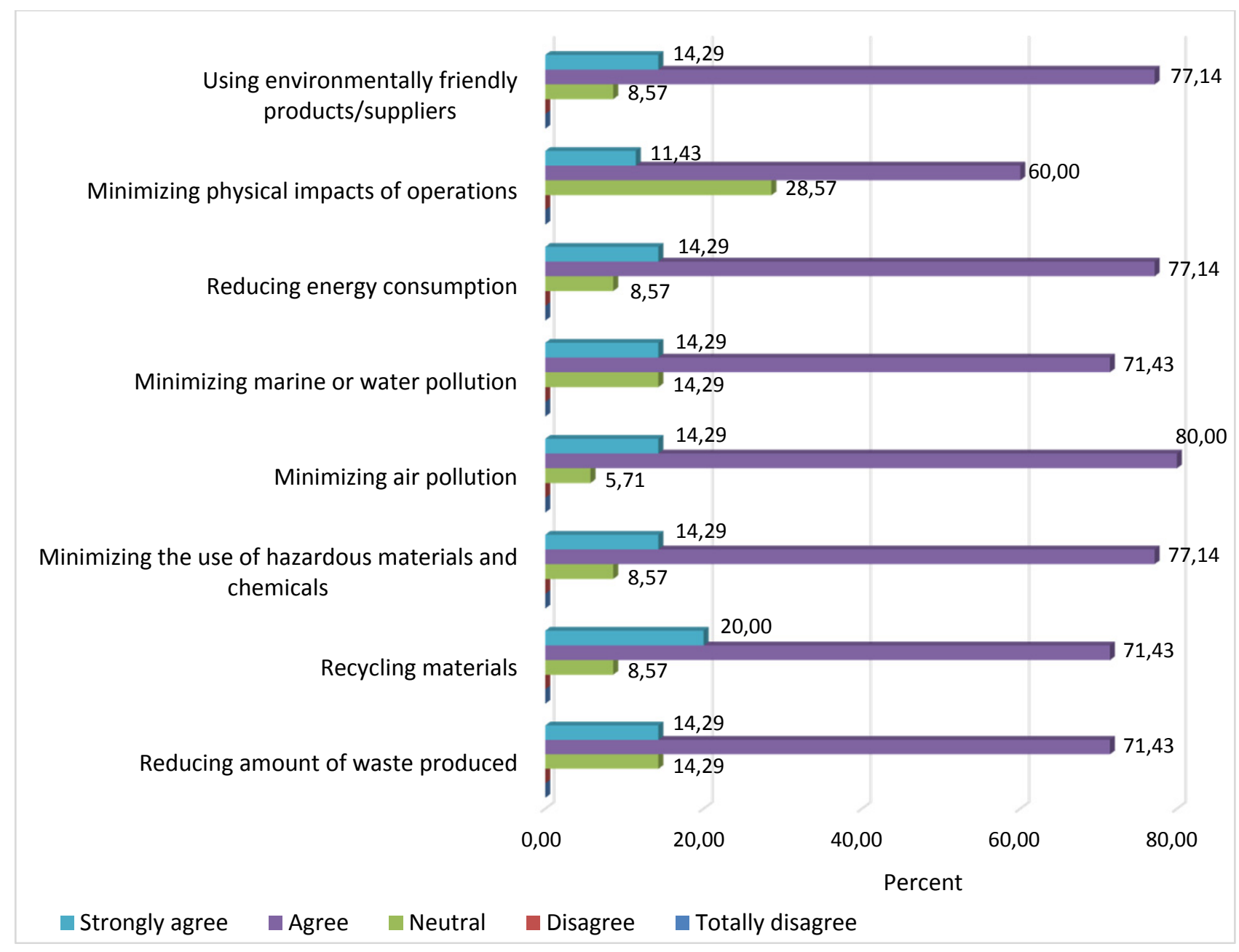

Figure 4. Benefits of cleaner production - case study

(source: Doorasamy, 2014)

Table 4. Test Statistics

\begin{tabular}{|l|c|c|c|c|c|c|c|c|}
\hline & $\begin{array}{c}\text { Using environ- } \\
\text { mentally friend- } \\
\text { ly products } \\
\text { /suppliers }\end{array}$ & $\begin{array}{c}\text { Minimiz- } \\
\text { ing physi- } \\
\text { cal impacts } \\
\text { of opera- } \\
\text { tions }\end{array}$ & $\begin{array}{c}\text { Reducing } \\
\text { energy } \\
\text { consump- } \\
\text { tion }\end{array}$ & $\begin{array}{c}\text { Minimiz- } \\
\text { ing marine } \\
\text { or water } \\
\text { pollution }\end{array}$ & $\begin{array}{c}\text { Minimiz- } \\
\text { ing air pol- } \\
\text { lution }\end{array}$ & $\begin{array}{c}\text { Ming the use } \\
\text { of hazard- } \\
\text { ous materi- } \\
\text { als and } \\
\text { chemicals }\end{array}$ & $\begin{array}{c}\text { Recycling } \\
\text { materials } \\
\text { cing } \\
\text { amount } \\
\text { of waste } \\
\text { produced }\end{array}$ \\
\hline Chi-square & $30.400^{\mathrm{a}}$ & $12.743^{\mathrm{a}}$ & $30.400^{\mathrm{a}}$ & $22.857^{\mathrm{a}}$ & $34.686^{\mathrm{a}}$ & $30.400^{\mathrm{a}}$ & $23.543^{\mathrm{a}}$ & $22.857^{\mathrm{a}}$ \\
\hline df & 2 & 2 & 2 & 2 & 2 & 2 & 2 \\
\hline $\begin{array}{l}\text { Asymptotic } \\
\text { significance }\end{array}$ & 0.000 & 0.002 & 0.000 & 0.000 & 0.000 & 0.000 & 0.000 & 2 \\
\hline
\end{tabular}


All of the p-values are less than 0.05, the level of The results of chi-square tests are shown in Table 5. significance. Hence, the scoring patterns for each statement across the options were not similar. Fig. 5 illustrates investment in environmental performance.

The company does not feel a need to invest in improving its environmental performance

The company is willing to invest what is necessary to improve its environmental performance

The company is willing to invest in improving its environmental performance, but only a small amount

The company has invested sufficiently in improving its environmental performance

$$
\text { ng }
$$

$$
0,00
$$

$$
20,00
$$

$$
40,00
$$$$
60,00
$$

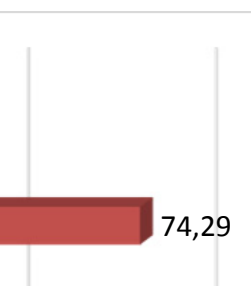

\section{Percent}

$\square$ Strongly agree $\quad$ Agree $\quad$ Neutral Disagree $\quad$ Totally disagree

\begin{tabular}{|c|c|c|c|c|}
\hline & $\begin{array}{l}\text { The company does } \\
\text { not feel a need } \\
\text { to invest in improving } \\
\text { its environmental } \\
\text { performance }\end{array}$ & $\begin{array}{l}\text { The company } \\
\text { is willing to invest } \\
\text { in improving its envi- } \\
\text { ronmental perfor- } \\
\text { mance, but only } \\
\text { a small amount }\end{array}$ & $\begin{array}{l}\text { The company is will- } \\
\text { ing to invest what is } \\
\text { necessary to improve } \\
\text { its environmental per- } \\
\text { formance }\end{array}$ & $\begin{array}{l}\text { The company has } \\
\text { invested sufficiently } \\
\text { in improving its } \\
\text { environmental } \\
\text { performance }\end{array}$ \\
\hline Chi-Square & $46.257^{\mathrm{a}}$ & $31.171^{\mathrm{a}}$ & $11.714^{b}$ & $41.229^{\mathrm{a}}$ \\
\hline df & 3 & 3 & 4 & 3 \\
\hline $\begin{array}{l}\text { Asymptotic signif- } \\
\text { icance }\end{array}$ & 0.000 & 0.000 & 0.020 & 0.000 \\
\hline \multicolumn{5}{|c|}{$\begin{array}{l}\text { a cells }(0.0 \%) \text { have expected frequencies less than } 5 \text {. The minimum expected cell frequency is } 8.8 \text {. } \\
\text { b } 0 \text { cells }(0.0 \%) \text { have expected frequencies less than } 5 \text {. The minimum expected cell frequency is } 7.0 \text {. }\end{array}$} \\
\hline
\end{tabular}

Figure 5. Investment in environmental performance (source: Doorasamy, 2014)

Table 5. Test statistics 
All of the p-values are less than 0.05 , the level of significance. Hence, the scoring patterns for each statement across the options were skewed. Fig. 6 illustrates benefits of a system designed to measure and manage environmental performance.

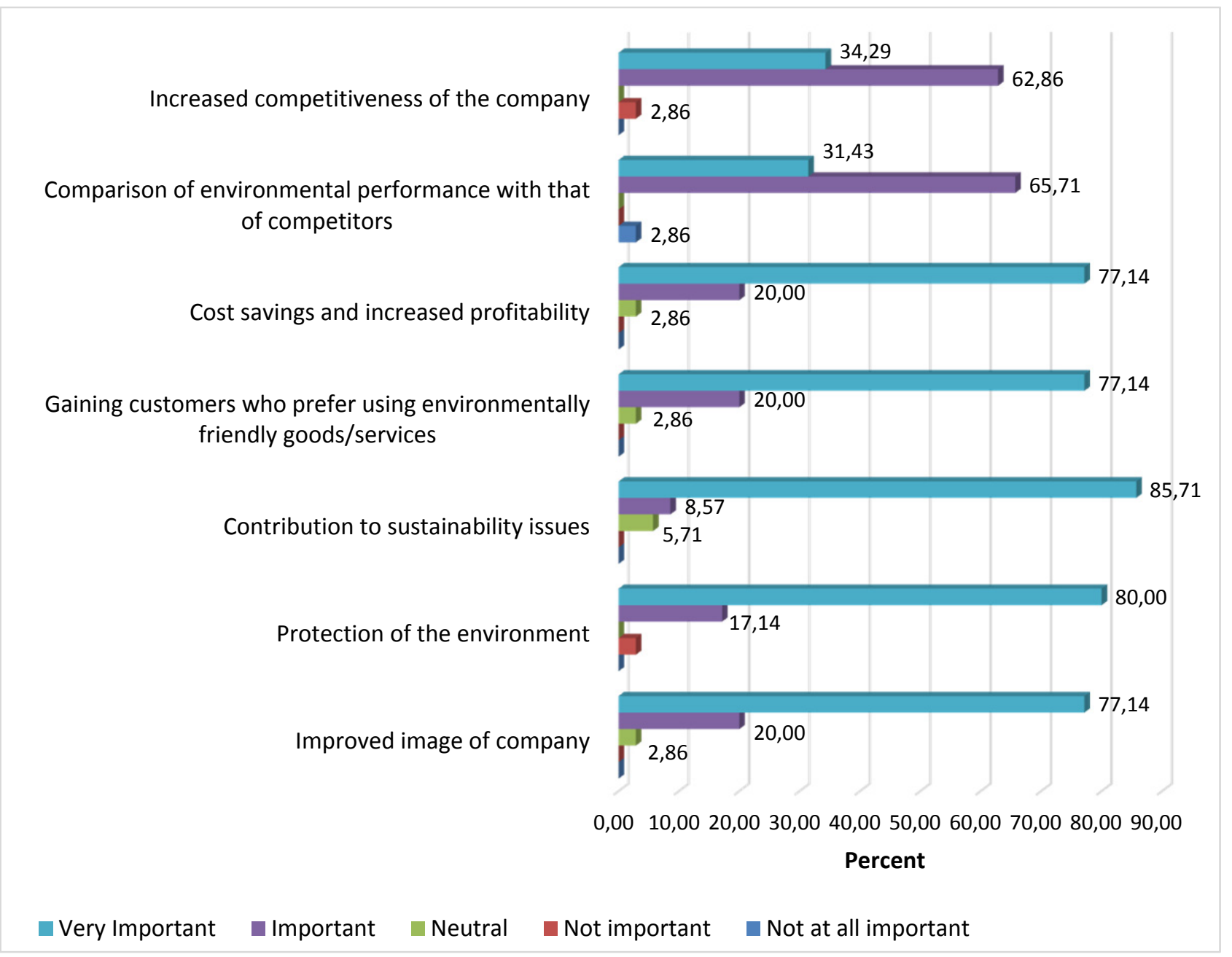

Figure 6. Benefits of a system designed to measure and manage environmental performance (source: Doorasamy, 2014)

The average level of agreement is $96.73 \%$. This is a high level of agreement with the statements that constitute this section. Only one statement has a $4 \%$ difference to the other levels of agreement of $97.14 \%$.

The analysis aimed to identify criteria implemented by the company to evaluate and select a system designed to measure and manage environmental per- formance by taking into consideration the expected benefits to the company. The results indicate that majority of the respondents consider sustainability issues as very important, followed closely by level of environmental protection.

The results of chi-square tests are shown in Table 6 . 
Table 6. Test statistics

\begin{tabular}{|c|c|c|c|c|c|c|c|}
\hline & $\begin{array}{l}\text { Increased com- } \\
\text { petitiveness } \\
\text { of the company }\end{array}$ & $\begin{array}{l}\text { Comparison } \\
\text { of environ- } \\
\text { mental per- } \\
\text { formance } \\
\text { with that of } \\
\text { competitors }\end{array}$ & $\begin{array}{l}\text { Cost sav- } \\
\text { ings and } \\
\text { increased } \\
\text { profitabil- } \\
\quad \text { ity }\end{array}$ & $\begin{array}{l}\text { Gaining cus- } \\
\text { tomers who } \\
\text { prefer using } \\
\text { environmental- } \\
\text { ly friendly } \\
\text { goods/services }\end{array}$ & $\begin{array}{l}\text { Contribution } \\
\text { to sustaina- } \\
\text { bility issues }\end{array}$ & $\begin{array}{l}\text { Protection } \\
\text { of the envi- } \\
\text { ronment }\end{array}$ & $\begin{array}{c}\text { Im- } \\
\text { proved } \\
\text { image of } \\
\text { company }\end{array}$ \\
\hline Chi-Square & $18.914^{\mathrm{a}}$ & $20.800^{\mathrm{a}}$ & $31.771^{\mathrm{a}}$ & $31.771^{\mathrm{a}}$ & $43.257^{\mathrm{a}}$ & $35.371^{\mathrm{a}}$ & $31.771^{\mathrm{a}}$ \\
\hline df & 2 & 2 & 2 & 2 & 2 & 2 & 2 \\
\hline $\begin{array}{l}\text { Asymptotic } \\
\text { signifi- } \\
\text { cance }\end{array}$ & 0.000 & 0.000 & 0.000 & 0.000 & 0.000 & 0.000 & 0.000 \\
\hline
\end{tabular}

All of the p-values are less than 0.05 , the level of significance. Hence, the scoring patterns for each statement across the options were not similar.
Fig. 7 illustrates challenges of applying systems to measure and manage environmental performance.

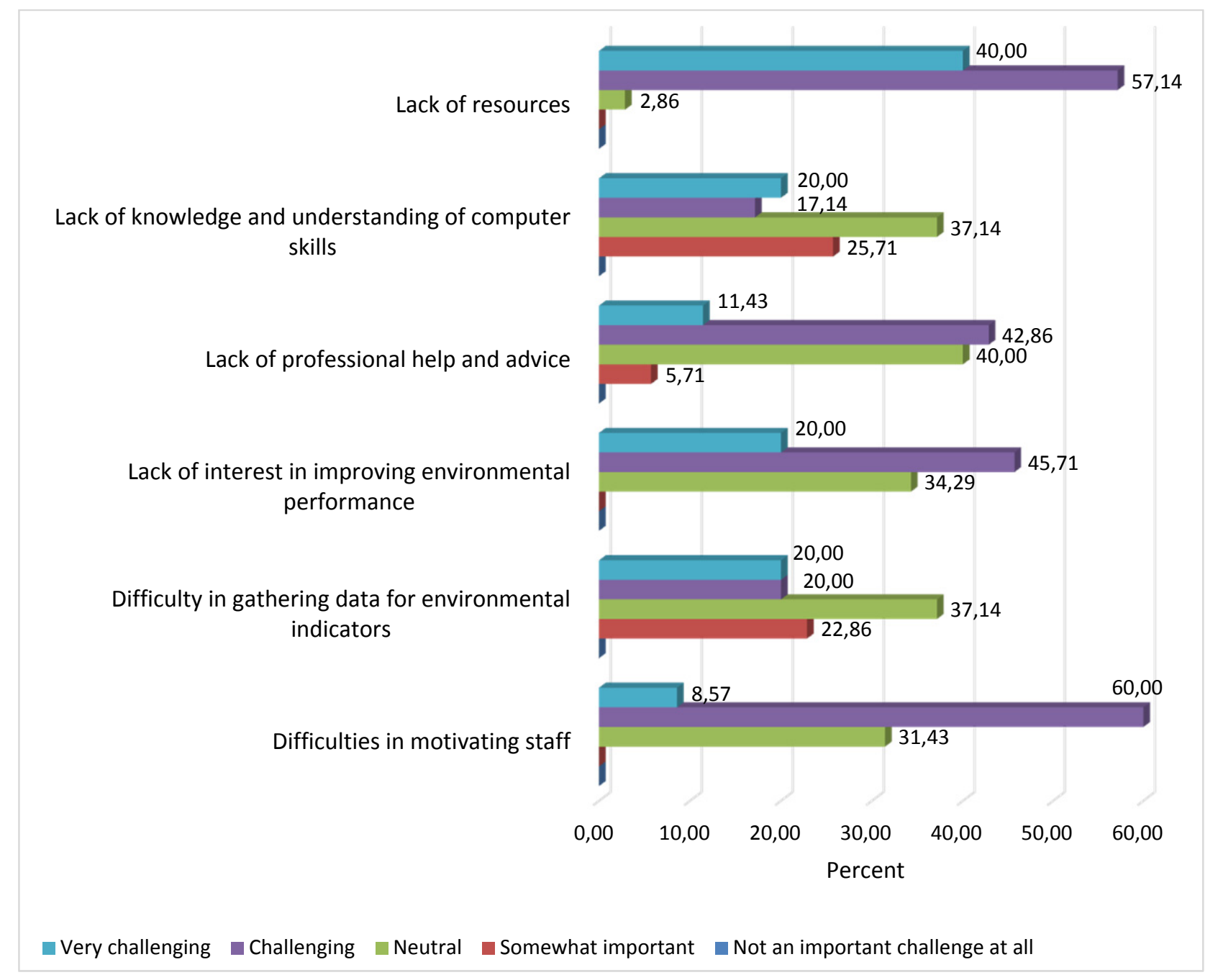

Figure 7. Challenges of applying systems to measure and manage environmental performance (source: Doorasamy, 2014) 
The data analysis was used to assess management's perception on the most important challenges in applying a system to measure and manage environmental performance. Results reveal that "lack of resources" is the most important challenge with a response rate of $97.14 \%$, followed by "difficulties in motivating staff", at response rate of $68.57 \%$. Interestingly, "lack of interest in improving environmental performance" was also rated high with $65.71 \%$ of respondents indicating this as a challenge.

\subsection{Correlations}

Patterns reflected on the correlation sheet reveal that there is a positive correlation between the company's environmental performance and environmental activities implemented to reduce environmental impact and pollution. Hence, it can be concluded that environmental activities practiced by the company has had a positive effect on the company's environmental performance.

Interestingly, the company's investment in improving environmental performance also has a high positive correlation to environmental activities adopted. It can be inferred that as investments in pollution prevention activities increases, environmental performance also increases.

Further, a positive correlation of 0.828 has been noted for the relationship between "increased competitiveness of the company" and "comparison of environmental performance with that of competitors." This suggests that respondents agree that the level of environmental performance impacts on the competitiveness of an organization in comparison to its competing industries. Hence, an organization can achieve competitive advantage by improving its environmental performance.

\subsection{Semi-structured interviews}

The study yielded the following results:

- The researcher, during the interview with the cost accountant of the company, discovered that the environmental costs are perceived to be insignificant and only accounted for annually using a traditional accounting system. Therefore, investment in CP technology to improve environmental performance and reducing environmental cost was not viewed as a necessary measure by the organization. It was also evident that the company only considers their waste disposal and water treatment costs as environmental costs. Scavone (2006, pp.1276-1285) states that by adopting an EMA system, a company can develop proactive environmental programs which, in turn, improve profitability and competitiveness, reduce business costs, increase worker productivity and morale, enhance brand image, and improve relations with regulators and local communities. She believes that companies that adopt proactive measures to address environmental issues are in an excellent position to identify problems and opportunities to introduce innovative solutions. It is essential for companies to generate reliable past- and futureoriented information by using environmental accounting decision tools such as EMA, to enable effective and efficient management of environmental consequences of the business operations.

- Their material losses are not evaluated and added to NPO costs. All raw materials used are allocated to product cost irrespective of whether they actually form part of the final product. Energy and system costs, as identified by MFCA, are also not considered when costing wastes. Therefore, no decisions are made toward improving production processes and moving toward CP technology. The cost of investing in $\mathrm{CP}$ technology is not justified, because of the inaccurate assessment of environmental costs resulting in it being underestimated. Environmental costs are also reflected under general overhead account and are not being traced back to the product or process. During the investigation using EMA, it had been discovered that the largest cost category was the material purchase value of NPO. It had been concluded that EMA could be used to support strategic decision making in companies for more effective product mixes, strategies, and investments that improve environmental performance of a company and also highlight the potential for large cost savings.

- Schmidt and Nakajima (2013, pp.358-369) found some weaknesses in conventional cost accounting (CCA) in that it cannot give all the required data. Monetary value flows are traced and interpreted as product cost in a CCA system. CCA focuses on cost figures for each product in each process, whereas MFCA checks mass balances in each process. CCA 
focuses on production costs of the whole company in monetary terms, whereas MFCA focuses on accuracy of cost figures of each process taking into account material losses (NPO). Reporting under MFCA highlights actual production costs by excluding the cost of raw material purchased that becomes waste and does not form part of the final product. Generally, companies focus on the input materials and the quantity of products produced from these inputs, not on the material losses generated from the specific process. Hyrslova et al. (2011, p.8) concluded that MFCA is a very important method of environmental and economic performance management.

\section{Conclusion}

\subsection{Conclusions drawn from literature review}

Recent paradigm shift of environmental management from pollution control to pollution prevention had led to the introduction of CP techniques and technologies. The emphasis of $\mathrm{CP}$ is on reducing waste at its source. CP techniques include low-cost strategies, such as good housekeeping to investments involving high capital cost, such as changes in technologies, production processes, or input product substitution. Many case studies have been cited in the literature review highlighting the benefits of adopting CP measures. However, in South Africa, CP is still very much in its infancy stage. Research shows that this is the only solution for companies that generate significant waste and consumed large amount of resources. Waste is a sign of inefficiency, and inefficient production processes impact negatively on a company's profitability and environmental performance. In order to identify which processes are inefficient, there is a need to trace material and energy flows.

MFCA, an EMA tool, traces the flow of material throughout the entire production process, highlighting inefficiencies. The most significant portion of environmental costs was NPO costs. Previous research has shown that MFCA accurately traces the monetary and physical amounts of NPO costs. It increases the transparency of environmental costs, allowing managers to identify saving opportunities by adopting CP techniques or technologies. This enables them to make informed investment decisions and to assess the benefits of adopting cleaner production techniques or technologies.

$\mathrm{CP}$ adoption is also promoted by the new waste legislation. Within the next 5-7 years, disposal to landfill of certain wastes such as waste containing carbon will be strictly prohibited. This means that companies will have no choice but to change their production processes or technologies to reduce waste generated. Implementation of proactive environmental strategies and CP is imperative to ensure future sustainability of organizations by improving their economic and environmental performance. CP options were provided in the literature review. Also a comparison of end-of-pipe technologies and CP technologies was presented in the literature review.

\subsection{Conclusions from empirical findings}

The aim of this research was not only to identify environmental costs of the production process but also to highlight scope for potential savings. During initial analysis, the focus was on what the company identified as environmental costs and also what other costs are environmental but concealed in other accounts.

The first objective of this study was to demonstrate the role of EMA in sustainable development and to identify the benefits of adopting $\mathrm{CP}$ technologies as compared to end-of-pipe technology based on primary and secondary literature as well as empirical findings.

A comprehensive review of the literature clearly highlighted the role of EMA in sustainable development, and the benefits of adopting CP technologies compared to end-of-pipe technologies were also presented. Various theories, approaches, and findings on the relationship between EMA, CP, and the impact on environmental and economic performance of the organization were discussed in detail in the literature review. Therefore, the first objective of the study has been achieved.

To conduct a CPA of the company's current production process to identify operational inefficiencies and to assess the efficiency and environmental impact of current technologies being used in steam generation process. 
To identify the environmental costs of the steam generation process, a CPA was completed.

The steam generation process revealed that large amounts of boiler ash between 20 and 60 tons per day are generated from the boilers. An average of $20 \%$ of this ash is made up of unburned coal. Hence, this process is inefficient and results in financial loss to the company as well as has negative impact on the environment. The $20 \%$ loss of coal becomes waste and needs to be evaluated and deducted from production cost. This was, however, not being done. In the case study, the boilers used for the generation of steam is more than 40 years old and are, therefore, considered obsolete, which could lead to inefficient steam production incurring high environmental costs and poor economic performance. $\mathrm{CP}$ is not being adopted by the company, although this strategy could improve both the organizations' environmental and economic performance. As the coal-fired boiler gets older, the coal used to replace the original fuel is usually poorer in quality: lower in heating value and higher in ash than the original design fuel (Sheldon, 2001, p.5).

\subsection{Environmental and economic impact}

Frequent disruptions are experienced by the company, resulting in loss in production. Losses because of downtime amounted to approximately R439, 101.80 according to company records. Frequent disruptions could be attributed to insufficient maintenance and poor housekeeping measures. Furthermore, the company incurs high maintenance cost for boilers. Managers are, however, unaware of the magnitude of maintenance cost. Schaltegger et al. (2010) confirm that these are signs of inefficiencies that become evident during the CPA.

The company has no environmental costs allocated to the steam production process. The only cost incurred according to financial records is the fixed and variable costs according to production cost schedule. Furthermore, NPO cost was not calculated for the large amounts of unburned coal found in the boiler ash. This generally forms a large proportion of environmental costs and should have been allocated to the steam production process. Instead, the entire purchase value of the coal is indicated as production costs (as per production cost schedule). The compa- ny uses a CCA system, which is inadequate to calculate "actual environmental" cost; hence, environmental costs are significantly underestimated. All other environmental costs are hidden under overhead accounts. Similar shortcomings of conventional management accounting practices in environmental cost consideration during internal decision making were reported by Ambe (2007, p.6).

In order to assess the company's current environmental performance, various procedures and policies were investigated.

The empirical results were as follows:

\section{- Environmental-related activities}

Environmental-related costs and estimation of contingent liabilities are considered by the company. However, environmental costs are not systematically traced back to production processes and products.

The following weaknesses in the company's current system in calculating the environmental costs were identified. Costs of waste disposal were not consistently gathered and evaluated, and the cost of handling of waste within the organization was seldom taken into account. Including material purchase value in waste was theoretically accepted but was never actually calculated. Furthermore, the environmental and technical departments in addition to the financial and cost accounting calculation records carry out recordings of data on amounts and costs of input/output materials, and so on. Technical controllers use this data rather than data contained in accounting records. It is evident from the findings that there are inconsistencies when compared to the accounting figures. Hence, poor communication is evident. It had also been found that environmental and technical managers have insufficient information about the magnitude of operational costs. Only accountants were exposed to this kind of information. Furthermore, comprehensive cost statements for environmental costs were not available. Hence, there is a need for increased awareness of the magnitude of environmental costs, more especially, the material purchase value of NPO contained in waste needs to be established. This information could be used to implement measures to improve material and process efficiency. 
Therefore, it can be deduced that the environmental costs reflected in the company records are incorrect, as most of the costs that should be included in the cost calculation are omitted. The reason for this is strongly attributed to the conventional accounting system being used by the company.

\section{- Perspectives of EMA}

Environmental information is reported to external stakeholders. However, this is not being done regularly and comprehensively as an EMA system would do. EMA will serve as a solid foundation for the effective implementation of an EMS (Mohr-Swart, 2008). Lack of resources had been reported as most challenging in implementing the environmental management systems. Difficulty in motivating staff has also been identified as a major challenge. Gil, Andres, and Salinas $(2007$, p.89) argue that management commitment and awareness of environmental responsibility significantly influence corporate strategy. Sinclair-Desgagne (2004, p.7) suggests that all business units need to be involved in environmental goal setting and implementation in order to successfully achieve environmental objectives.

- Communication between accounting department and environmental department

The environmental manager is the only individual involved in handling environmental issues and, at times, environmental issues are outsourced to an environmental specialist. Poor interdepartmental communication is evident. There is also no link between systems for collecting financial and nonfinancial data. Recent developments in EMA emphasize the greater need for accounting information when making decisions regarding environmental projects (Qian and Burritt, 2008, p.244).

Hence, the next objective of the study was achieved.

- To investigate barriers to CP implementation according to management

Barriers to the adoption of cleaner production technologies by the company are high initial capital cost, which has been identified as the major barrier to adopting CP technologies, followed by additional infrastructure requirement. It is also clearly evident that managers perceive that organizations experience poor financial performance by investing in $\mathrm{CP}$ technologies. Relaxed regulation and law enforcement are also contributing factors to the lack of adoption of CP technologies by companies in South Africa.

Therefore, all the objectives of the study has been achieved.

\subsection{Theoretical contributions of $\mathrm{CP}$}

The issue is that most companies are seeking to achieve short-term profitability instead of trying to find ways to ensure their long-term sustainability. This study added to the body of knowledge on CP and sustainable development. Managers would be able to evaluate and analyze how they can improve both their environmental and economic performance in the future and attain their sustainability targets. Barriers to the adoption of CP technologies by the company are high initial capital cost, which has been identified as the major barrier to adopting $\mathrm{CP}$ technologies, followed by additional infrastructure requirement. Managers perceive that organizations experience poor financial performance by investing in CP technologies (Schaltegger et al., 2010). Relaxed regulation and law enforcement are also contributing factors to the lack of adoption of CP technologies by companies in South Africa.

\section{Reference}

[1] Academy of Science of South Africa (ASSAF), 2011. Technological innovations for a low carbon society conference (online). Available: http://www.assaf.co.za.

[2] Acemoglu, D., Akcigit, U., Hanley, D., Kerr, W., 2012. Transition to Clean Technology.

[3] Ambe, M. C., 2007. Environmental Management Accounting in South Africa. Status, challenges and implementation framework. D. Tech. Tshwane University of Technology.

[4] Baas, L., 2007. Integrated Environmental and Economic Performance Assessments for Strategic Planning and Policy Analysis in Paper Manufacturing. Journal of Cleaner Production, 15:1205-1216.

[5] Bartolomeo, M., Bennett, M., Bouma, J.J, Heydkamp, P., James, P., Wolters, T., 2001. Environmental management accounting in Europe: current practice and future potential. European Accounting Review, 9 (1):31-52. 
[6] Bennett, M., Schaltegger, S., Zvezdov, D., 2011. Environmental management accounting. Review of Management Accounting Research, S: 53-84.

[7] Bosworth, M., Hummelsmose, B., Christiansen, K., 2001. Cleaner Production Assessment in Dairy Processing. Denmark: COWI Consulting Engineers and Planners AS.

[8] Bras, B., Realff, M., Carmichael, C., 2004. Integrated Environment and Economic Performance Assessment for Strategic Planning and Policy Analysis in Paper Manufacturing. CPBIS project - B-4: 5-7, final project report to CPBIS.

[9] Burritt, R.L., Herzig, C., Tadeo, B.D., 2009. Environmental Management Accounting for Cleaner Production: the case of a Philippine rice mill. Journal of Cleaner Production, 17:431439.

[10] Chang, H-C., 2007. Environmental Management Accounting Within Universities: Current State and Future Potential. Thesis. Degree of Doctor of Philosophy. School of Accounting and Law. RMIT Business and RMIT University

[11] Christ, L.K., Burritt, R.L., 2013. Environmental management accounting: the significance of contingent variables for adoption. Journal of Cleaner Production, 41:163-173 (online). Available: http://elsevier.com/locate/jelepro

[12] Delana, R., 2013. Valued platform to illustrate impact and profitability of RECP program. Cleaner Production Conference (online). Available: http://www.energyforecastonline.co.za/art icles/cleaner-production-conference

[13] Despeisse, M., Oates, R.M., Ball, D.P., 2013. Sustainable manufacturing tactics and crossfunctional factory modelling. Journal of Cleaner Production (online), 42, pp.31-41. Available: http://www.sciencedirect.com/science /article/

[14] Doorasamy, M., 2014. Using Environmental Management Accounting to identify benefits of Cleaner Production in KwaZulu-Natal: A case study. Masters Dissertation. Durban University of Technology.

[15] Dvarionienè, J., Kruopienè, J., Stankevi-čienè, J., 2012. Application of cleaner technologies in milk processing industry to improve the environmental efficiency. Clean Technologies and Environmental Policy, 14 (6): 1037-1045.
[16] Environmental Strategies (online), 2013. Available: http://www.unido.org/en/what-we-do/envir onment

[17] Ferreira, A., Moulang, C., Hendro, B., 2010. Environmental management accounting and innovation: an exploratory analysis. Accounting, Auditing \&Accountability Journal, 23 (7): 920948.

[18] Foelkel, C., 2008. Eco-efficiency and cleaner production for the eucalyptus pulp and paper industry (online). Available: http://eucalyptus com.br

[19] Fore, S., Mbohwa, G.T., 2010. Cleaner production for environmental conscious manufacturing in the foundry industry. Journal of Engineering Design Technology 8(3):314-333 (online). Available http://dutlib.dut.ac.za:2057/docview/ 1012253156

[20] Frondel, M., Horbach, J., Rennings, K., 2004. End-of-Pipe or Cleaner Production? An Empirical Comparison of Environmental Innovation Decisions Across OECD Countries. ZEW Discussion papers, No. 04-82 (online). Available: http://hdl.handle.net/10419/24090

[21] Hyrslova', J., Vagner, M., Palasek, J., 2011. Material Flow Cost Accounting (MFCA)- Tool For The Optimization of Corporate Production Processes. Business, Management and Education 9(1): 5-18.

[22] Jasch, C., 2009. Environmental and Material Flow Cost Accounting Principles and Procedures (Eco-Efficiency in Industry and Science Series, vol. 25). Journal of Industrial Ecology. Springer science and Business Media: Berlin (pp.832834).

[23] John Thompson information/reviews, 2009. Available online: http://www.jobvine.co.za/in sight/company/johnthompson

[24] Jonall, P., 2008. Environmental Management Accounting (EMA), Management Accounting including Environmental Management: 2.

[25] Mendes, L., 2012. Clean Technologies and Environmental Management: A Study on a Small Diary Industry in Brazil. Resources and Environment, 2(3):100-106 (online). Available: http://journal.sapub.org/re 
[26] Ministry of Economy, Trade and Industry of Japan (METI). 2010. Environmental Management Accounting: MFCA Case Examples; METI: Tokyo, Japan.

[27] Mohr-Swart, M., 2008. An Environmental Management Accounting Model for the South African Mining Industry. Doctor of Technology in the Department of Environmental, Water and Earth Sciences, Tshwane University of Technology.

[28] Mousavi, M.M.S., Hosselini, Z.S., Resalati, H., Mahdavi, S., Garmaroody, E.R., 2013. Papermaking potential of rapeseed straw, a new agricultural-based fibre source. Journal of Cleaner Production 52:420-424.

[29] Mousavi, M.M.S., Hosselini, Z.S., Resalati, H., Mahdavi, S., Garmaroody, E.R., 2013. Papermaking potential of rapeseed straw, a new agricultural-based fibre source. Journal of Cleaner Production 52:420-424.

[30] Pandey, A.K., 2007. Identification and Assessment of Cleaner Production technologies and appropriate technology management strategies and methods in the South African vehicle industry. Masters of Engineering (Technology Management). University of Pretoria.

[31] Pandey, A.K., Brent, A.C., 2008. Application of technology management strategies and methods to identify and assess cleaner production options: cases in the South African Automotive industry. South African Journal of Industrial Engineering, 19(2), pp.171-182.

[32] Peres, I., Domil, A.E., Pere, S.C., 2010. Capturing environmental costs by using activity based costing method. Anale. Seria Stiinte Economice, pp.719-726.

[33] Pons, M., Bikfalvi, A., Llach, J., Palcic, I., 2013. Exploring the impact of energy efficiency technologies on manufacturing firm performance. Journal of Cleaner Production (online), 52:134144. Available: http://elsevier.com/locate /jclepro

[34] Promoting sustainable use of industrial materials. 2013. Pulp and Paper industry material (online). Available: http://industrialresources councilorg/material/pulpandpaperindustrymater ials $/ \mathrm{t}$
[35] Qian, W. and Burritt, R., 2008. The Development of Environmental Management Accounting: An Institutional View. In: Schaltegger, S., Bennett, M., Burritt, R. and Jasch, C. eds. Environmental Management Accounting for Cleaner Production. Springer Netherlands, 233-248. Available: http://dx.doi.org/10.1007/978-1-4020 -8913-8_12.

[36] Scavone, G.M., 2006. Challenges in internal environmental management reporting in Argentina. Journal of Cleaner Production (online), 14:1276-1285. Available: http://www.sciencedi rect.com

[37] Schaltegger, S., Csutora, M., 2012. Carbon accounting for sustainability and management. Status quo and challenges. Journal of Cleaner Production, 36:1-16.

[38] Schaltegger, S., Bennett, M., Burritt, R.L., Jasch, C., 2010. Eco-efficiency in industry and science. Environmental Management Accounting for Cleaner Production. $5^{\text {th }}$ edition. Springer Science and Business Media. UK.

[39] Schmidt, M., 2012. Material Flow Cost Accounting in the production industry. Industrial Ecology Management, pp.241-255.

[40] Schmidt, M., Nakajima, M., 2013. Material Flow Cost Accounting as an approach to improve resource efficiency in manufacturing companies. Resources (online), 2:358-369. Available: http://www.mdpi.com/journal/resour ces

[41] Sheldon, R.W., 2001. Process to improve boiler operation by supplemental firing with thermally beneficiated low rank coal. US Patent, 6325001B.

[42] Sinclair-Desgagne, B., 2004. Corporate Strategies for Managing Environmental Risk. The International Library of Environmental Economics and Policy xx:1-7. Scientific Series 2004s-43, Montreal.

[43] South African National Cleaner Production centre, 2013. Case study in good organization management and governance practices (online). Available http://unido.org/cp

[44] Staniskis, J.K., Stasiskiene, Z., 2013. Environmental management accounting in Lithuania: exploratory study of current practices, possibilities and strategic intents. Workshop - Environ- 
mental management accounting: Towards an internationally validated procedure.

[45] Struwig, F.W., Stead, G.B., 2013. Research: Planning, Designing and Reporting. Second Edition. Pearson Education South Africa (Pty) Ltd

[46] Sygulla, R., Bierer, A., Gotze, U., 2011. Material Flow Cost Accounting - Proposals for Improving the Evaluation of Monetary Effects of Resource Savings Process Designs. $44^{\text {th }}$ Conference on Manufacturing Systems. Wisconsin, USA. Available online URL:https://tu-chemnitz .de/wirtschaft/bwl3/DownloadAllgemeinOffen/4
4thCIRP_MFCA.pdf (Accessed 3 September 2013).

[47] V'an, H., 2012. Environmental benefits and its statement in Environmental Management Accounting. Ph.D. University of Szeged.

[48] Žarković, D.B., Rajaković-Ognjanović, V.N., Rajaković, L.V., 2011. Conservation of resources in the pulp and paper industry derived from cleaner production approach. Resources, Conservation \& Recycling, 55 (12): 1139-1145.

[49] Zikmund, G.W., 2004. Business Research Methods. $7^{\text {th }}$ edition. United States of America. Thomson South-Western. 